\title{
POEMAS PARA NO LEER: APUNTES SOBRE LA RECEPCIÓN DE LA POESÍA DE VANGUARDIA
}

\section{NOT-TO-READ POEMS: NOTES ABOUT THE RECEPTION OF VANGUARD POETRY}

\begin{abstract}
What happens with the reception of a poem when its composition goes beyond the traditional use of the linguistic sign and it gives the reader new elements for the construction of meaning? How can we build up meaning from the «unexpected»? What do vanguard poems propose to the receptor? These are some of the questions that we will try to answer in this article, using as objects of study, poetic pieces of Dadaism, Concrete Poetry and Spanish Experimental Poetry. Through our journey, we will be pointing, analyzing and proposing hypotheses about the reception of that kind of poem, which demands the participation of the reader in a very high level. We will lean on the Reception Theory of Literature, on Semiotics and on the Aesthetic Effect Theory.
\end{abstract}

Key words: Vanguard Literature; Reception Theory; Aesthetic Effect Theory. 


\section{RESUMEN}

¿Qué ocurre con la recepción del poema cuándo su composición sobrepasa el uso tradicional del signo lingüístico y da al lector nuevos elementos para la formación de sentido? ¿Cómo se construye la significación a partir de lo inesperado? ¿Qué proponen al receptor los poemas vanguardistas? Estas son algunas de las preguntas que intentaremos contestar en este artículo, utilizando como objetos de estudio piezas poéticas del dadaísmo, de la poesía concreta y de la poesía experimental española. En nuestro recorrido iremos apuntando, analizando y proponiendo hipótesis acerca de la recepción de poemas de esa índole, que exigen la participación lectora a niveles muy altos. Nos apoyaremos en la Teoría de la Recepción de la Literatura, en la Semiótica y en la Teoría del Efecto Estético.

Palabras clave: Literatura de Vanguardia; Teoría de la Recepción de la Literatura; Teoría del Efecto Estético.

Fecha de recepción: 21 de septiembre de 2020.

Fecha de aceptación: 24 de octubre de 2020.

Cómo citar: Massucci Calderaro, Sérgio (2020), «Poemas para no leer: apuntes sobre la recepción de la poesía de vanguardia», en Actio Nova: Revista de Teoría de la Literatura y Literatura Comparada, 4: 385-415.

DOI: https://doi.org/10.15366/actionova2020.4.017 


\section{INTRODUCCIÓN}

Es inherente a cualquier texto lingüístico la coexistencia de dos niveles de información: la semántica y la estética. Es posible, incluso, imaginar una clasificación textual según el criterio de la intención informativa que cada tipo de texto guarda en sí. Prospectos de medicamentos o manuales de instrucciones de calderas de gas serían buenos ejemplos de texto lingüístico de intención casi puramente semántica. Las circulares de la dirección de un colegio dirigidas a las familias puede que ya posean algún grado más de intención estética, aunque lo que predomine siga siendo la semántica. El texto periodístico estaría un peldaño por encima de las circulares escolares, y los textos publicitarios quizás un escalón más arriba de los periodísticos. Sin embargo, en todos ellos la primacía de la intención informativa semántica sobre la estética es muy evidente.

Es solamente en el texto literario que podemos empezar a vislumbrar cambios más importantes. En cierta prosa barroca o en la de un autor vanguardista como James Joyce la intención estética está explícita, mucho más que en la prosa realista, por ejemplo. Pero el lugar por excelencia de los textos con alta carga de intención informativa estética es la poesía, aunque también en ella se pueden diferenciar varios niveles. En el sentido de la intención informativa $-\mathrm{y}$ en muchos otros sentidos, por supuesto-, un poema parnasiano es muy distinto a una pieza poética vanguardista. Y si cerramos el foco en la vanguardia, aún es posible seguir con la clasificación. En el extremo estético, podríamos poner los poemas fónicos, letristas y visuales.

Hasta aquí hemos sido genéricos, pero ahora, una vez hecha esa pequeña introducción, nos volcaremos con atención con ese tipo de texto dónde la información semántica, al menos en apariencia, se queda en segundo plano en detrimento de la estética. ¿Qué quiere decir eso, al final? ¿Qué consecuencia tiene para el lector el hecho de que un objeto artístico haya sido construido en gran medida a partir de la intención estética? ¿Ese tipo de pieza poética, tan poco semántica, comprometería la formación de sentido? Intentaremos averiguarlo. 


\section{EL LECTOR ATRAPADO}

Empezaremos mirando el signo lingüístico. Su comportamiento irá cambiando según avancemos de textos donde predomina la intención informativa semántica hacia los textos de intención informativa estética. Para que no nos quedemos en el aire, podemos ejemplificar. El cuento «La calavera», de Emilia Pardo Bazán, empieza con «El chiflado habló así: ». La frase está hecha de signos lingüísticos completos; todos los significantes tienen sus correspondientes significados pegados a ellos, al menos dentro de la comunidad que comparte el idioma castellano. Tiene también un encadenamiento sintáctico fácilmente reconocible. La formación de sentido no presenta problemas para el receptor; se da de manera inmediata. En un movimiento natural producido por los textos de intención semántica, el lector será llevado para fuera del texto en busca de proyecciones de imágenes sugeridas por la frase en cuestión. Si tomamos un grupo de lectores más o menos homogéneo en sus características históricas, sociales y culturales -por ejemplo y en pocas palabras: residentes en el centro de Madrid actualmente, nivel universitario, entre los 30 y los 50 añoséstos abandonará el texto de Pardo Bazán por unos instantes para buscar en su repertorio mental la proyección de un «chiflado», que podría tener el aspecto de Jerry Lewis, de un ex compañero de la facultad que considerase chiflado o de un tipo que deambula por la Plaza Mayor increpando a la gente. Si, en el acto de la lectura, el receptor se da cuenta de que la historia de Pardo Bazán es de hace más de un siglo, podría actualizar su imagen para la época, cambiándole la ropa y el peinado al chiflado. Al leer «habló así», seguido por los dos puntos, seguramente surgirá la sensación de expectativa y puede incluso que el chiflado mueva la boca. De esta manera, grosso modo, se va realizando poco a poco la concreción en la mente lectora, en un continuo tránsito entre el interior y el exterior del texto, entre las palabras impresas en el papel y el universo mental del receptor, entre esas dos instancias que se van retroalimentando durante el acto de lectura. El éxito de ese proceso está garantizado, en su base, por el descifre del signo lingüístico. Una frase como «El chibumba habló así:» alteraría completamente la recepción, ya que el significante «chibumba» no encuentra significado inmediato en el repertorio del lector, y el signo no puede ser desvendado automáticamente. Sería la falencia del signo lingüístico. Si ponemos ahora sobre la mesa la dimensión vertical de las obras literarias propuesta por Ingarden (in: Warning, 1989: 35) como el camino del lector hacia la concreción del texto -formada por los estratos fonético, semántico, esquemático y el de las objetividades representadas-, veremos que él también depende, para 
su éxito, de la decodificación de los signos lingüísticos, es decir, del nexo entre significante (equivalente al estrato fonético) y significado (equivalente al estrato semántico). Sin esa relación primera, el esquema de Ingarden estaría seriamente comprometido y el pasaje a los dos estratos siguientes, en consecuencia, se vería malogrado. Esa complicada recepción es típica en las literaturas de vanguardia, donde el proceso de formación de sentido debería llevar el lector a caminos distintos de los tradicionales. Para seguir con nuestros apuntes, cojamos un ejemplo extremo: el poema fónico Gadji Beri Bimba ${ }^{1}$, compuesto en 1916 por el dadaísta Hugo Ball.

\section{Gadji Beri Bimba}

gadji beri bimba glandridi laula lonni cadori gadjama gramma berida bimbala glandri galassassa laulitalomini gadji beri bin blassa glassala laula lonni cadorsu sassala bim gadjama tuffm i zimzalla binban gligla wowolimai bin beri ban o katalominai rhinozerossola hopsamen laulitalomini hoooo gadjama rhinozerossola hopsamen bluku terullala blaulala loooo

zimzim urullala zimzim urullala zimzim zanzibar zimzalla zam elifantolim brussala bulomen brussala bulomen tromtata velo da bang bang affalo purzamai affalo purzamai lengado tor gadjama bimbalo glandridi glassala zingtata pimpalo ögrögöööö viola laxato viola zimbrabim viola uli paluji malooo

tuffm im zimbrabim negramai bumbalo negramai bumbalo tuffm i zim gadjama bimbala oo beri gadjama gaga di gadjama affalo pinx gaga di bumbalo bumbalo gadjamen gaga di bling blong gaga blung

Ese texto puede parecerse mucho más a un juego o incluso a una trampa y, de hecho, tiene un poco de las dos cosas. Sabemos de las intenciones provocativas y de burla de los dadaístas, pero por detrás de ellas hay propuestas estéticas serias que deben ser tenidas en cuenta. Gadji Beri Bimba quiere liberar las palabras de su destino sígnico. Más que eso: quiere renovar las significaciones, rompiendo con el esquema de los nexos entre significantes y significados corrientes y previamente dados al receptor. Quiere abandonar los referentes suscitados por los antiguos significantes y abrir la puerta para el establecimiento de nuevos referentes basados únicamente en la faceta sonora de las palabras, que tendrían entonces el poder de amplificar las posibilidades de formación de sentido a través de información casi

\footnotetext{
${ }^{1}$ https://www.lyrikline.org/es/poemas/gadji-beri-bimba-von-hugo-ball-10297 (último acceso: 04/05/2020).
} 
puramente estética: al no haber un sentido previamente dado, se abren las puertas para sentidos varios. Si el poema dijera «Gajo», ese signo seguramente llevaría el lector hacia una fruta de su repertorio mental; pero el poema dice «Gadji», un anti-signo que no llevará al lector, al menos en un primer instante, a ningún sitio. El receptor de «Gadji» no sale del poema; ahí se queda. No logra alcanzar ningún enlace extra poema y va a buscar alguna aclaración en las palabras siguientes. Tampoco consigue enlaces externos para «Beri»y «Bimba»y, entonces, podrá volver a leer desde el principio o seguir buscando conexiones para «glandridi», «laula» etc. De todos modos, ya estará atrapado por el poema. Cabe también la posibilidad, bastante plausible, de abandono de la lectura, pero esa no nos interesa aquí. Lo que sí nos interesa es intuir el comportamiento del lector de buena voluntad que, una vez atrapado por el poema, empieza, entonces, a realizar enlaces. Al contrario que los poemas tradicionales, compuestos exclusivamente por signos lingüísticos integrales, la pieza en cuestión -que atiende a la segunda articulación del lenguaje, pero no a la primera- abre al receptor un amplio abanico de posibilidades para la formación de sentido, que van a depender, por supuesto, de las condiciones históricas y sociales del lector o grupo de lectores. Una hipótesis es la del intento de formación de sentido por proximidad fonética. Dentro de eso, «Gadji» puede arrastrar el lector a Cádiz, gaditano, o también al rio Ganges, o a hadji y otras referencias del mundo musulmán o hindú. «Beri» podría sugerir la enfermedad beriberi, mientras «Bimba» tiene, por casualidad, significado en español (sombrero), por lo que se podría llegar a concretar «Gadji Beri Bimba» como un gaditano enfermo con sombrero ${ }^{2}$. El camino de la proximidad fonética, palabra a palabra, puede ser curioso e incluso divertido. Sin embargo, otras hipótesis tal vez sean más apropiadas, ya que esta, de formación de sentido por similitud sonora, sigue utilizando el patrón del signo lingüístico, digamos, tradicional, y al fin y al cabo acaba enganchando significados corrientes a los significantes, aunque estos sean ininteligibles en un primer momento.

Hacer justicia a ese poema, creemos, es respetar su autonomía. Para generar significación, los significantes-y todo el poema, en el caso de una aprehensión global de la pieza- no tienen necesariamente que enlazarse a un significado mundano, no tienen que ser «una idea estancada de una dorada ciénaga», para utilizar los términos del manifiesto de

\footnotetext{
$2 \mathrm{Al}$ leer este artículo para revisarlo, mi mujer, española, me comenta que es bastante probable que el lector español actual conecte «Bimba» con la imagen de la modelo Bimba Bosé o, también, con la marca Bimba y Lola.
} 
Tristán Tzara ${ }^{3}$. El significado puede ser nuevo, totalmente nuevo, y puede que no haga falta emprender el viaje al exterior del poema para encontrarlo. El contenido del poema, su «mensaje», pasa a ser su propia forma, y, en consecuencia, la forma del poema pasa a ser lo que éste tiene de contenido. Es decir, el receptor no tiene que buscar el contenido fuera de la pieza artística, sino en su propio interior. Peter Bürger (2010) piensa que desde mediados del siglo XIX la dialéctica forma-contenido se va inclinando definitivamente hacia la forma, y los objetos artísticos, cada vez más, pasan a necesitar la participación de la sensibilidad receptora para la formación de sentido. En los casos extremos alcanzados por las vanguardias, al no encontrar referentes extra poema, el lector tiene que volcarse en la obra y solamente en la obra, buscando significaciones a través únicamente de la experiencia estética. El impacto en el receptor es grande, ya que contradice la expectativa que probablemente tendría antes de empezar la lectura de la pieza poética. Aunque el lector hubiese adaptado su expectativa al ambiente vanguardista -ya sea el lector de la época de las vanguardias históricas o el de ahora, pasado más de un siglo- el poder de impacto sigue vigente, más todavía en el caso específico de los poemas fónicos. Lo que tiene delante de sus ojos le exige una actitud drástica de lectura, muy distante de una serena visión contemplativa. Según Walter Benjamin (2003: 90), «Con los dadaístas, la obra de arte dejó de ser una visión cautivadora o un conjunto de convincentes sonidos y se convirtió en un proyectil que se impactaba en el espectador».

Ante un poema como Gadji Beri Bimba, vemos un buen ejemplo de la «degradación de la función representativa realizada por la vanguardia» (Bürger, 2010: 46). Bürger introduce términos que nos parece interesante comentar aquí. Llama obra de arte no orgánica a las vanguardistas; y a las no vanguardistas las denomina orgánicas. $\mathrm{Y}$ analiza:

El artista que produce obras orgánicas (en adelante lo llamaremos «clásico», sin querer introducir un concepto clásico de obra de arte) manipula su material como algo vivo, cuyo significado, surgido de situaciones concretas de la vida, él respeta. En cambio, para el artista vanguardista, el material es solo material. Su labor no es otra que la de matar la «vida» del material, es decir, extraerlo de su contexto funcional que le da significado. Mientras el clásico reconoce en el material al portador de un significado y lo atiende, el vanguardista ve un símbolo vacío al que solo él es capaz de darle significado. Por consiguiente, el clásico manipula su material como totalidad, en tanto el vanguardista lo saca de su contexto de vida, lo aísla, lo fragmenta (2010: 100).

3 http://www.estagiodeartista.pro.br/artedu/cultuarte/talleres/manifies_dadaista.htm (último acceso: 06/05/2020). 
Es fácil percibir ese procedimiento volviendo a Gadji Beri Bimba, donde los signos -si es que podemos realmente llamarlos signos- están fragmentados, es decir, la unidad significante-significado fue rota por el artista de vanguardia, que toma como elemento nada más que el significante, dejando el significado abierto. En cambio, en la obra orgánica, los signos están vivos, íntegros y completos; son significantes plenos de significado, resultando en un tipo de recepción mucho más automatizada. La recepción de la obra orgánica se muestra inadecuada para la obra no orgánica, mucho más abierta y enigmática a la vez. Si el lector intenta adoptar el mismo camino de recepción de la obra orgánica para recibir la obra no orgánica, ésta se resistirá a adquirir sentido. Su lectura, de este modo, se verá dificultada o, al menos, será más trabajosa.

Siempre que vemos u oímos palabras, nuestra tendencia es buscar inmediatamente en ellas sus significados, que a su vez nos llevarían a un sentido general para el todo del texto. Al notar que no vamos a encontrar lo que buscamos, que los significantes no traen significados, experimentamos el shock, que muchas veces puede derivar en sensaciones de frustración, hostilidad y el consecuente abandono de la lectura. De ahí vendría la «impopularidad» o la «anti popularidad» de la poesía de vanguardia, frente a la «popularidad» de poemas, por ejemplo, románticos o realistas. Quien usa esos términos es el filósofo español José Ortega y Gasset (2016: 49-100), en su texto La deshumanización del arte, de 1925, publicado originalmente, por lo tanto, en una época muy cercana al surgimiento de las vanguardias históricas. Ortega y Gasset dirige su explicación sobre lo popular y lo impopular en el arte dividiendo los receptores en dos «castas»: aquella que no lo entiende (la mayoría, la masa) y aquella que lo entiende («una minoría especialmente dotada»). Sin entrar en la polémica del análisis de la sociedad que los términos de Ortega y Gasset pueden suscitar, creemos nosotros que «el arte nuevo» (otro término del autor español) sería impopular precisamente por la imposibilidad que supone al receptor encontrar un camino semántico para la formación de sentido. Esa busca ya nace fallida de antemano. Ahora bien, más que una cuestión de castas, pensamos que estos dos tipos de recepción tendrían mucho más que ver con la buena voluntad del lector ante la obra vanguardista. En el caso de Gadji Beri Bimba y otros poemas fónicos y visuales, hechos como la falta de significados para los significantes y la rotura del eje sintagmático imponen al receptor una tarea adicional, que muchas veces no estará dispuesto a realizar. Ortega y Gasset propone una interesante metáfora: si miramos a un jardín a través de una ventana de cristal, podemos fijar la vista en las flores o, ajustando el globo ocular, fijarnos en el cristal. Contemplar las flores sería lo más automático, mientras 
volcar la atención al cristal nos supondría un cierto trabajo de ajuste de la visión. Ese ejemplo puede servir para ilustrar dos tipos de recepción de la imagen ante nuestros ojos. El autor concluye:

la mayoría de la gente es incapaz de acomodar su atención al vidrio y transparencia que es la obra de arte: en vez de esto, pasa al través de ella sin fijarse y va a revolcarse apasionadamente en la realidad humana que en la obra está aludida. Si se le invita a soltar esa presa y a detener la atención sobre la obra misma de arte, dirá que no ve en ella nada, porque, en efecto, no ve en ella cosas humanas, sino sólo transparencias artísticas, puras virtualidades. (2016: 59)

El pensador español, en el fragmento seleccionado arriba, habla de «realidad humana» $\mathrm{y}$ «cosas humanas», $\mathrm{y}$, al fin y al cabo, ese es el tema central de su ensayo La deshumanización del arte. Aquí, volvamos rápidamente a Peter Bürger, porque nos interesa conectarlo con Ortega y Gasset. Creemos posible relacionar los conceptos de arte orgánico y no orgánico de uno con los de arte humanizado y deshumanizado del otro. Ambos utilizan como elemento diferenciador entre las artes su carácter referencial. En su funcionamiento, tanto el arte orgánico como el humanizado usan gran carga de referentes externos a la obra, llevando obligatoriamente al receptor para fuera del arte en su proceso de formación de sentido. En cambio, el arte no orgánico y el deshumanizado retienen al receptor en el interior de la obra, pues no usa, o usa muy poco, el artificio de la referencia externa, humana, orgánica. Y, si volvemos al principio de este artículo, podemos rescatar también las ideas de obras de arte donde predomina la intención semántica o la intención estética, que también guardarían relación con lo humanizado/orgánico y lo deshumanizado/no orgánico. Ortega y Gasset, que escribió el referido ensayo en pleno frenesí vanguardista, veía claramente en el panorama artístico una tendencia a la purificación del arte, entendiendo por purificación precisamente el aumento de la intención estética de las obras, en detrimento de lo semántico y referencial. Y completaba:

Esa tendencia llevará a una eliminación progresiva de los elementos humanos, demasiado humanos, que dominaban en la producción romántica y naturalista. Y en este proceso se llegará a un punto en que el contenido humano de la obra sea tan escaso que casi no se le vea. Entonces tendremos un objeto que sólo puede ser percibido por quien posea ese don peculiar de la sensibilidad artística. (2016: 60)

Hoy sabemos que no fue así. Las vanguardias históricas fueron efímeras, como no podrían dejar de serlo; lo efímero es una de sus características. Aunque hayan dejado huella -patente claramente, por ejemplo, en las vanguardias del post II Guerra y en mucho de lo que se hace actualmente en términos de ciberpoesía-, pasado ya más de un siglo, lo orgánico 
y lo humanizado siguen predominando en la literatura. Pero tal vez el volumen del arte no orgánico, poco en comparación con el del orgánico, no pueda ser considerado propiamente un fracaso. Su impopularidad, como decía Ortega, es natural y vendría de la dificultad de entendimiento, lo que puede ser traducido, en otras palabras, en la dificultad del receptor para mantenerse dentro del texto, por su afán de buscar un sentido semántico externo donde simplemente no lo hay. Un texto deshumanizado no guarda relación con exterioridades humanas. Él mismo funda su propio universo, invitando el lector a entrar en él, a habitarlo, a jugar y a disfrutar, pero siempre ahí, atrapado en su interior.

\section{EL ACTO DE LEER LA OBRA DE VANGUARDIA}

Sigamos un poco más con la problemática del signo lingüístico en el ambiente literario vanguardista. Tradicionalmente, el significante, en textos no vanguardistas, es visto como un mediador. La imagen acústica que sugiere al receptor sirve como medio de conectar el propio receptor a un concepto. Esa mediación se hace a través de una materia visual (escrita y leída) que se convertirá en imagen acústica y, finalmente, en concepto. Según Roland Barthes (2012: 60), el significante necesita la materia para existir, pero la materia no le es suficiente. Es decir, un significante que sea pura materia, sin un correspondiente concepto que le dé significado, tal vez ni siquiera pueda ser clasificado como significante, ya que no mediaría en nada, no tejería ningún puente entre la materia y el concepto, no generaría significación. Sería materia pura, casi como una piedra en la calle, un estímulo material sin mayores consecuencias. ¿Pero será que, de verdad, significantes como «gadjii» y «beri» no generan realmente ninguna significación? En este punto vemos imprescindible, si vamos a hablar de significación, ir más allá de la clásica relación significante-significado y abordar el concepto de valor, indicado también por Saussure en su Curso de Lingïística General (Saussure, 2012: 158-170).

El valor, junto con la significación, forma parte de los hechos de la palabra. Mientras la significación resulta de la relación significante-significado (podemos imaginarla verticalmente), el valor está dado por la relación de la palabra con otras palabras (imaginemos un plano horizontal). Ambos hechos son fundamentales para el funcionamiento de la palabra. Son dos hechos distintos, pero complementarios. La significación presupone el «cambio» de una imagen acústica por un concepto. El valor presupone la «comparación» de 
la imagen acústica con otras imágenes acústicas. Cambio y comparación son términos básicos para comprender, respectivamente, la significación y el valor lingüístico. En «iSal de ahí, perro!», todas las palabras tienen significación y valor. En «iPerro perro perro, perro!» todas las palabras siguen teniendo significación, pero el valor se pierde; todos los términos son iguales, no hay medida de comparación y el encaje entre ellos se ve comprometido. Una buena imagen puede ser la de un puzle. Cada pieza tiene dos caras. Pongamos que la faz con el dibujo sea el significante, que siempre va a tener, en la faz opuesta, un significado. Esa pieza, a la vez, se relaciona con las otras piezas del puzle, y en esa relación va a tener un valor específico. Si todas las piezas del puzle son iguales (como en «Perro perro perro, perro!»), no hay encajes posibles. Saussure (2012) y Barthes (2012), hablando del mismo tema, sugieren, entre otros, el ejemplo monetario (para que podamos terminar de comprender ese concepto tan abstracto): una moneda de cinco francos, la podemos cambiar por pan (la barra de pan pasaría a ser el significado de la moneda); a la vez, la misma moneda la puedo comparar con otras monedas de valores distintos (y, entonces, tendríamos la idea exacta de su valor). El valor, por lo tanto, no surge solo, sino por comparación dentro de un sistema. No se define positivamente, sino en negativo, de acuerdo con las relaciones que establece con otros elementos del sistema. «Su característica más exacta es ser lo que los otros no son» (Saussure, 2012: 164).

Si, para la producción de sentido, entran en escena tanto la significación como el valor, Gadji Beri Bimba se abre al receptor en una doble vertiente. La imagen acústica de «gadji» puede ser cambiada por un abanico de conceptos mucho más grande que, por ejemplo, la imagen acústica de «chiflado». Su poder de cambio tiene una amplitud que los significantes previamente fijados en el idioma no tienen. En cuanto al valor, la situación puede ser controvertida. Podemos considerar que «gadji» realmente no se opone a nada, no se puede comparar con nada, ya que simplemente «gadji» no existe, o al menos no existía hasta el momento de la lectura. Una vez leído, «gadji» pasa a existir y -ahí viene la controversia-, entonces, se opone de forma radical a absolutamente todo. Si «chiflado» se opone claramente a palabras como «inflado» (por proximidad sonora) o «sensato» (por contraste de sentido), «gadji», en un principio, no encuentra claros oponentes, lo que puede hacer que se vuelva en contra de todas las palabras de un léxico, oponiéndose a ellas. Si, en un principio, «gadji» no tiene valor, podrá adquirirlo en el acto de la lectura. Volviendo a la imagen del puzle, la pieza «gadji» parece no encajar con ninguna otra; sin embargo, una vez inaugurada en el acto de la lectura, se puede convertir en una pieza comodín, con múltiples 
capacidades de encaje, algo como una pieza moldeable que a todo se puede acoplar. En Gadji Beri Bimba -y en tantos otros poemas vanguardistas, no solamente los poemas fónicos-, más que actualizar el texto en el acto de la lectura, el receptor prácticamente inaugura el texto, dando significación y valor a signos que, antes de la lectura, no tenían ni significación ni valor (y tal vez, por esa razón, ni siquiera pudiesen ser llamados signos).

Podríamos ahora rever el sistema estratificado propuesto por Ingarden. Antes decíamos que su esquema - pensado como la vereda del lector hacia la concreción del textose veía afectado en el poema dadaísta por la falta de significados anclados a los significantes. Pero puede que no. Si en realidad los signos vanguardistas inauguran tanto significación como valor, el estrato semántico pasa a existir y puede evolucionar al estrato esquemático y al de las objetividades representadas. Pero eso se daría de manera particular e increíblemente abierta para cada receptor o grupo homogéneo de receptores. Creemos que lo fundamental es no negar la posibilidad de sentido al poema fónico, sino de incrementar esas posibilidades. Los poemas fónicos, los poemas visuales y tantas otras modalidades poéticas de la vanguardia, muchas veces tasadas apresuradamente como pura burla, broma o simple provocación, puede que tengan, al fin y al cabo, mucho más que ofrecer al lector que los poemas no vanguardistas, al menos en lo que concierne a la formación de sentido. De herméticos, pasan a ser enormemente abiertos; de sinsentido, pasan a tener múltiples sentidos. Y, además, tocan un interesante hilo que tiene que ver con el origen mismo de los signos lingüísticos.

Volviendo rápidamente a Saussure y a su Curso de Lingüística General, vemos que el lingüista suizo introduce el concepto de valor exponiendo su teoría de cómo el pensamiento se organiza en la materia fónica (2012: 158-160), algo que él mismo clasifica como un hecho «en cierto modo misterioso». Para él, tanto el plano de las ideas como el de los sonidos son dos masas amorfas, confusas e indefinidas. El trabajo de la mente humana sería organizar esas masas en fragmentos, conectando pedazos de ideas y sonidos para, así, ir formando signos. Éstos, a su vez, tendrían la capacidad de articularse con otros fragmentos, posibilitando el lenguaje. Es un proceso en que el pensamiento caótico necesita de significantes para organizarse; los significantes, los encontrará dentro de una substancia fónica también amorfa. Para que lo confuso se organice y tome forma, ambas masas amorfas se ven forzadas a descomponerse en unidades. La lengua, en ese contexto, sería una intermediaria entre el pensamiento y el sonido. 
Bien. El concepto es complejo y hemos intentado retomarlo, arriba, en líneas generales, para poder aplicarlo al proceso de lectura. En obras no vanguardistas, la recepción no presenta demasiados sobresaltos. Las primogénitas masas amorfas de pensamiento y sonido ya están previamente organizadas en signos lingüísticos. Ya en el caso del poema vanguardista, particularmente en Gadji Beri Bimba, nuestro objeto de estudio hasta el momento, los fragmentos sonoros también están organizados, pero no hay un orden identificable en el plano del pensamiento. Es decir, tenemos ahí pequeñas porciones sonoras sin ideas correspondientes, como sería de esperar en un texto escrito. Esa quiebra de expectativa lleva al lector a ponerse en contacto otra vez con su primitiva masa amorfa de pensamientos, buscando en ella alguna idea que se pueda corresponder con los significantes dispuestos en el poema. Es como volver al camino primigenio de la formación de los signos, pero de manera inversa. Los sonidos ya están dados, pero les faltan conceptos. Ese trabajo corre totalmente a cargo del receptor. Poner al receptor otra vez en contacto con ese mágico y misterioso proceso de formación de signos es, desde nuestro punto de vista, uno de os grandes logros de ese tipo de poema fónico.

Añadamos ahora otro ejemplo a nuestro análisis:

Figura 1: vai e vem ${ }^{4}$ :

\section{vai e vem}

$\mathbf{e}$

\section{vem e vai}

Ese es el poema vai e vem, compuesto en 1959 por el poeta concreto José Lino Grünewald. Tal vez no hiciera falta, pero lo traducimos del portugués al español: va y viene.

\footnotetext{
4 Extraído de https://ditirambospoesia.wordpress.com/2012/08/16/vai-e-vem/ (último acceso: $15 / 06 / 2020)$.
} 
Antes de avanzar, retomemos rápidamente los principales conceptos que hemos comentado respecto a Gadji Beri Bimba y apliquémoslos aquí. A diferencia de nuestro ejemplo dadaísta, vai e vem está constituido por signos lingüísticos integrales, es decir, tienen significantes y significados que pueden ser inmediatamente identificables, así como cada signo también tiene su claro valor de oposición a otros semejantes. Aun así, el poema no llega a lanzar totalmente al receptor a un referente exterior. Decimos «totalmente» porque creemos sea posible que, por unos momentos, el lector sí salga del poema y proceda a la concreción del «ir»y «venir» de manera externa, alcanzando el estrato esquemático y el de las objetividades representadas. Puede que, por ejemplo, las significaciones alcanzadas le sugieran la imagen de un tren que va y viene de estación a estación, de una abeja yendo y viniendo entre las flores o de su histórico profesional de idas y venidas de un empleo a otro. Ese tránsito entre el poema y el mundo real es posible pero no del todo probable. Aunque el lector encuentre claramente significados para los significantes «va», «y» y «viene», la busca de referentes externos se presenta tortuosa. Es fácil deducir lo diferente que sería la lectura de un verso como «La mariposa va y viene» si lo comparamos al va y viene del poema concreto. En «La mariposa va y viene» la concreción se daría dentro de límites muy bien demarcados. Habría, por supuesto, posibilidades de variación -el color de la mariposa, por ejemplo, no está dado, así como el escenario en que ésta va y viene-. Ya en nuestro poema concreto, aunque el lector salga por unos instantes del texto, acabará volviendo. Vai e vem no está construído solo por signos lingüísticos. El elemento espacial también tiene significación, y el lector de buena voluntad querrá verificar cuál es. Por lo tanto, puede que el poema lleve el lector hacia afuera, pero él retornará y probablemente ahí se quedará, atrapado. Al lado de la información semántica, la información estética juega un papel muy importante para la formación de sentido. El poema no habla propiamente de nada, de un objeto, de un paisaje, de una persona, de un sentimiento o de un hecho en concreto. Por su plasticidad y por la disposición espacial de sus elementos -incluso de los espacios en blanco-, esta pieza poética parece intentar inducir una lectura dinámica que proporcionaría la sensación de vaivén en el propio receptor. El poema, entonces, no «habla» del vaivén, sino que proporciona la sensación del vaivén, sin apenas la necesidad de ayuda de referentes externos. Yendo más lejos, podemos decir que tal poema no proporciona solamente la sensación del vaivén, sino, también, un vaivén real de los músculos oculares del receptor mientras este deambula por el espacio de la obra, que permite lecturas en varias direcciones. Nuestra hipótesis es que, mientras busca un sentido semántico para el poema, es inevitable que la lectura proporcione al receptor el movimiento 
de vaivén. En ese caso, el lector, sin saberlo, ya habría aprehendido -y experimentado en su propia piel- el sentido estético del poema. Su búsqueda de sentidos externos sería en vano. Respecto a eso, comenta Wolfgang Iser (1996: 54-55) algo interesante. Este autor habla de una tensión constante entre el sentido estético y el semántico (denominado por él «discursivo») durante el acto de la lectura, y le da un carácter excluyente: si el receptor alcanza la construcción de sentido a través de una conexión externa al poema, ya no podrá, en ese momento, lograr una comprensión estética de la obra. Aún según Iser, el sentido empezaría a perder su carácter estético y a ganar carácter referencial cuando el lector se preguntase por el significado del poema. En ese instante, la pieza dejaría de significar a sí misma y el efecto estético se perdería. Tenemos que hacer dos aclaraciones: la primera es que Iser, cuando teje esa reflexión, se refiere a textos de ficción en general. Si nos volcamos específicamente en la vanguardia, y particularmente en la vanguardia extrema representada aquí por poemas fónicos y visuales, nos daremos cuenta de que, en nuestros ejemplos, la intención estética de los textos es muy evidente, lo que favorecería que el lector fuera empujado a una recepción igualmente estética, dejando de buscar referentes externos de significación. La segunda observación, que es una continuación de la primera, es precisamente sobre la expectativa del receptor. Grupos de receptores social e históricamente homogéneos que no tengan información previa sobre los procedimientos vanguardistas tenderán a forzar las puertas de la pieza poética en busca de sentidos semánticos externos; se preguntarán por el significado del poema. En cambio, grupos de receptores más familiarizados con las vanguardias tendrán menor posibilidad de ir en busca de un sentido semántico para el poema y más probabilidad de satisfacción con la información estética de la obra.

Iser (1996) dirige sus estudios a textos de ficción en prosa. Pero queremos contrastar algunas de sus conclusiones en relación con el tipo de poesía de vanguardia que venimos utilizando como objeto de estudio. Según él, el receptor tiene que crear representaciones a partir de la información esquematizada que el texto en si le da. El límite del texto es, precisamente, suministrar al lector las orientaciones para que él mismo proceda al montaje de imágenes en su mente, como si fuera un manual de instrucciones. Ahí tendríamos el pasaje del «artefacto» (el texto) al «objeto estético» (el texto más su recepción) - para usar los términos de Jan Mukarovsky (1971)-, proceso que sería común a toda literatura de ficción. Sin embargo, la vanguardia nos trae innumerables casos especiales. Vai e vem, por ejemplo, no favorece la creación de imágenes, como ya hemos visto. La propuesta de este poema -y de la mayoría de los poemas concretos, así como de muchas obras poéticas 
vanguardistas- va en dirección contraria: quiere frenar la producción de representaciones externas y mantener al lector dentro del espacio del poema. Es posible incluso cuestionarse sobre el carácter ficcional de tales experimentos; ellos son, en sí mismos, hechos concretos; no llevan al lector a un mundo inexistente de imágenes mentales, sino que lo mantienen, durante la lectura, experimentando sensaciones que pueden incluso llegar a ser físicas, obligando, en el caso específico de vai e vem, a un movimiento de los músculos oculares ya no en una dirección tradicional de izquierda a derecha, línea por línea, sino en diversas direcciones en un mismo espacio físico delimitado (la hoja), dejando los ojos del receptor enredados, yendo y viniendo dentro del poema. Por lo tanto, con vai e vem, podríamos estar situados, por lo tanto, al margen de estudios como los de Iser, que suponen como punto de partida, para describir el acto de leer, textos literarios ficcionales que propician la formación de imágenes mentales exteriores al texto, aunque por él dirigidas, y que tienen como punto de partida la lectura en sentido único, del inicio al final. Es decir, todo lo contrario de vai e vem, que puede ser leído en múltiples direcciones y que no busca la producción de representaciones por parte del receptor.

En gran parte, pasa lo mismo con mucho de los preceptos de la Teoría de la Recepción de la Literatura, que están basados en la representación, en la construcción de las «objetividades representadas» a partir del «objeto intencional» dado por los textos, rescatando algunos términos de Ingarden. Una vez que el texto no tiene una intención explícitamente representativa, la simple aplicación de esas teorías se ve comprometida. Los lugares de indeterminación de Ingarden pueden ser un buen ejemplo de lo que acabamos de decir. A priori, éstos existirían en toda obra literaria: «Todo objeto, persona, suceso, etc., representado en la obra literaria de arte, contiene gran número de lugares de indeterminación, especialmente en las descripciones de lo que ocurre a la gente o a las cosas» (Ingarden in Warning, 1989: 37). Si retomamos el ejemplo de Emilia Pardo Bazán ya utilizado aquí, vemos que en «El chiflado habló así:» lo único que está determinado respecto al personaje es que es un chiflado, pero no sabemos nada de su apariencia. El lector, entonces, podrá proceder a determinar algunos de los puntos indeterminados, quizás poniéndole al chiflado una ropa, una barba o incluso un tono de voz. Avanzando en la lectura, es probable que el texto determine algunos puntos sobre el chiflado que estaban indeterminados, y entonces el receptor tendrá que rever y actualizar sus determinaciones anteriores. Este proceso, que culmina con la «concreción» (otro término acuñado por Ingarden) del contenido literario, pasa constantemente durante el acto de lectura, pero claro, siempre y cuando hablemos de 
textos que representan objetos fuera del texto en sí. Textos de vanguardia como vai e vem no tienen intención representativa. Además, en ese caso específico, el poema está compuesto básicamente por dos formas verbales y no, por ejemplo, de sustantivos o adjetivos, clases de palabras que podrían empujar más fácilmente al lector hacia la busca de representaciones. $\mathrm{Al}$ final, entonces, ¿quién va y viene en ese poema? ¿Quién es el sujeto de esos verbos? Puede que el sujeto no sea nadie más que la propia palabra del poema, que va y viene, o, como mucho, el globo ocular del lector, que también va y viene mientras lee, y esas posibilidades tal vez sean las únicas dónde podríamos detectar algún lugar indeterminado en ese poema. De todos modos, en ambos casos (que el sujeto de los verbos sea el propio poema o el propio lector), no hay lectura posible -al menos en un primer momento- fuera del texto. Dentro del espacio físico de la pieza poética, todo parece estar determinado. Se podrían objetar nuestras hipótesis imaginando que el lector de vai e vem podría perfectamente salir en busca de un sujeto para los verbos, determinando en su mente receptora lo que entonces estaría indeterminado por el texto. Ese sujeto podría ser, entonces, un coche, un pájaro o un bailarín haciendo el movimiento de ir y venir, determinado por el lector, de acuerdo con su repertorio, a partir de un lugar de indeterminación sugerido esquemáticamente por el texto. Pero creemos sea muy poco probable esta opción. Si se tratara de un poema de corte tradicional, no vanguardista, donde los versos se suceden uno debajo del otro y la lectura se realiza de izquierda a derecha, en un eje temporal, la hipótesis de la busca y representación de un sujeto externo al poema puede que fuese más realizable.

\footnotetext{
Vai e vem

Vem e vai

Vai e vem

Vem e vai

Vai e vem

Vem e vai
}

Pero vai e vem no es así. El poema de José Lino Grünewald está dispuesto de tal forma que el lector tiene la visión integral del poema de golpe, en una rápida mirada. Pronto, el receptor se da cuenta de que no lo tiene que leer línea por línea, sino que se trata de un juego con otras reglas. Ese hecho, por sí solo, ya es un cambio de expectativa del lector en relación a la pieza poética que tiene delante. El receptor, por lo tanto, va a afrontar la lectura de otra manera, diferente de la tradicional. Nos parece bastante probable que, de entrada, se vean frenados sus impulsos de buscar sentidos semánticos más allá del texto. Estará él 
preocupado en dar orden a las letras y palabras ahí dispuestas y, casi sin notarlo, ya estará sumergido en el movimiento ocular de vaivén proporcionado por el poema. Es importante percibir que el poema no habla del vaivén, sino que proporciona el vaivén. El sujeto de los verbos, entonces, es el propio lector o las propias palabras, y no un personaje externo. $\mathrm{Al}$ no favorecer el flujo, digamos, natural de lectura, la pieza poética inserta al lector en un ambiente donde los significados no residen solamente en los signos lingüísticos. Por eso se dice sobre la poesía visual que elementos como la disposición en la página, los espacios en blanco, la tipografía e incluso el color tienen poder de significación. Sin ellos, la lectura sería otra. Basta imaginar, por ejemplo, un poema de Antonio Machado: nada cambiaría en su recepción si los versos estuvieran escritos en Arial o Garamond, con espacios entrelíneas de 1,0 o 2,0, con alineación a la izquierda o la derecha, con las letras negras o azules, con todo el poema en una página o con una parte en una página y la continuación en la página siguiente. Todos esos elementos no tendrían importancia.

Pero de lo que hablábamos era de los lugares indeterminados que, una vez determinados por el lector, resultan en la concreción. Nos parece que aquí, en vai e vem, no existen estos lugares, o al menos no de la forma descrita por Ingarden para los textos literarios, es decir, no existen indeterminaciones que tengan que ser llenadas con imágenes externas al poema. No existen huecos, pues todo ya está dicho. Los respectivos goces del receptor inmerso en la lectura de un poema vanguardista y de uno no vanguardista van en direcciones distintas. Mientras la pieza no vanguardista proporcionaría placer a través de la representación y la determinación de lugares indeterminados, el poema de vanguardia produce placer no por la representación, sino por ser una experiencia lúdica concreta que ocurre dentro de las propias líneas del poema. Mientras el poema no vanguardista puede ser comparado con un manual de instrucciones de un juego que tiene que ser montado por el lector, un poema vanguardista como vai e vem es un juego que ya está montado, esperando solamente a que venga el lector a darle al on para que se ponga en marcha ahí mismo, concretamente, delante de sus ojos. Los dos dependen del receptor para su funcionamiento, pero el modo de jugar es distinto. En el no vanguardista, el esquema del texto depende del receptor para su concreción, que operará a través de representaciones. El texto vanguardista también depende del receptor para concretarlo, pero esa concreción acontece por otros caminos, no los de la representación directa. El poema de vanguardia no representa una realidad; él mismo conforma su propia realidad. 


\section{REPRESENTACIÓN X REFLEXIÓN}

Volvemos rápidamente a Iser para empezar este apartado. En su texto «La estructura apelativa de los textos» (Warning, 1989: 133-148) encontramos una dilucidadora comparación entre textos de los siglos XVIII, XIX y XX respecto al uso de los lugares indeterminados. El texto del siglo XX utilizado como ejemplo por el autor -el Ulises de Joyceno es poesía, pero sí es vanguardia, y es posible seguir, con el debido cuidado, el hilo de sus comentarios. Particularmente interesante para el contexto de este artículo nos parece la afirmación de que

Cuando, así pues, en los textos modernos, se elimina toda significación representativa, queda garantizada en el proceso de recepción la oportunidad de que el lector, enfrentado a la reflexión, consiga relacionarse con sus propias representaciones (p. 146)

Creemos que, en este pequeño fragmento, se esconde la entrada al camino que buscamos. Hemos visto que vai e vem «elimina toda significación representativa». Siguiendo a Iser, una vez eliminada tal representación, cabe al lector enfrentarse a la reflexión y relacionarse con sus «propias representaciones». ¿Qué podrá eso querer decir? En la lectura de un poema no vanguardista, el receptor está envuelto en un mundo de representaciones sugeridas directamente por el texto. Él sabe que «flor» es «flor» y que «amon» es «amor», cabiendo solamente establecer pequeñas conexiones para rellenar los espacios vacíos y determinar lo indeterminado de manera prácticamente automática durante el proceso de lectura. Aunque el lector del poema no vanguardista pueda leer y releer varias veces la pieza poética que tiene delante, volviendo a versos ya leídos o empezando a leer todo el poema una vez terminada la primera lectura, él siempre estará procurando atar los signos impresos a elementos de su repertorio de posibles representaciones, objetivando culminar con la comprensión del significado del poema. Entretenido con la búsqueda de representaciones, no le queda, a su mente lectora, mucho espacio ni tiempo para reflexionar. La reflexión puede llegar, eso sí, una vez cerrado el libro, en forma de pensamientos indirectamente relacionados con el poema leído. En el caso de vai e vem, creemos que el poema también entretiene y envuelve al lector, pero no precisamente en la busca directa de representaciones, incluso porque hay muy pocos elementos lingüísticos susceptibles de representación directa (nada más que tres signos: «vai», «e», «vem»). Podemos imaginar que, como dice Iser, en el acto de 
lectura de vai e vem el receptor está «enfrentado a la reflexión». Primero, a la reflexión para desvendar el juego visual y espacial del poema; después, posiblemente, a la reflexión del propio sentido de la existencia de un poema de tal índole y, por fin, quizás, a reflexiones externas al poema que, entonces, estarían relacionadas con «sus propias representaciones». Lo que tenemos que notar es que, en un poema no vanguardista $-\mathrm{y}$ podemos coger como ejemplo un fragmento del poema Tú no te irás, de Rafael Alberti, que dice «el viento que va y viene»-, el camino para la formación de representaciones está abierto al lector, que es inducido a concretar lo que sugiere el texto para formar la imagen, quizás, del viento que va y viene, arrastrando hojas secas en una acera en una tarde nublada de otoño. Esa representación no sería una representación totalmente propia del lector, sino inducida en gran medida por los significantes del texto. La diferencia con el «va y viene» vanguardista puede que sea sutil, pero importante. El receptor no es empujado a representar nada inmediatamente en el momento de la lectura; estará, como ya hemos dicho, reflexionando sobre otros temas internos del poema. La representación podrá venir más tarde, y no estará tan directamente conectada con las frases del poema, sino con una idea general y vaga de la pieza poética, que podrá dejar huellas en el receptor. Sólo para ejemplificar: entre una infinidad de posibilidades el receptor podrá, una vez leído el poema y realizadas las reflexiones de carácter no representativo, llegar a concretarlo relacionándolo con su vida amorosa llena de idas y venidas con varias parejas, o recordando un viaje que hizo por muchas ciudades cuando era joven, sin reservas y teniendo constantemente que ir y venir en busca de un alojamiento para pasar la noche. Los caminos receptivos, por lo tanto, parecen tener esa diferencia fundamental: el poema de Rafael Alberti llevaría el lector, primero, a la representación, y después, quizás, a reflexiones externas, al tiempo que el poema de José Lino Grünewald, en un proceso inverso, llevaría el lector, primero, a las reflexiones, y después, quizás, a algún tipo de representación indirecta.

Quisiéramos ahora añadir a este artículo su último objeto de estudio. 
Figura 2: Poema circular (una pelicula... $)^{5}$

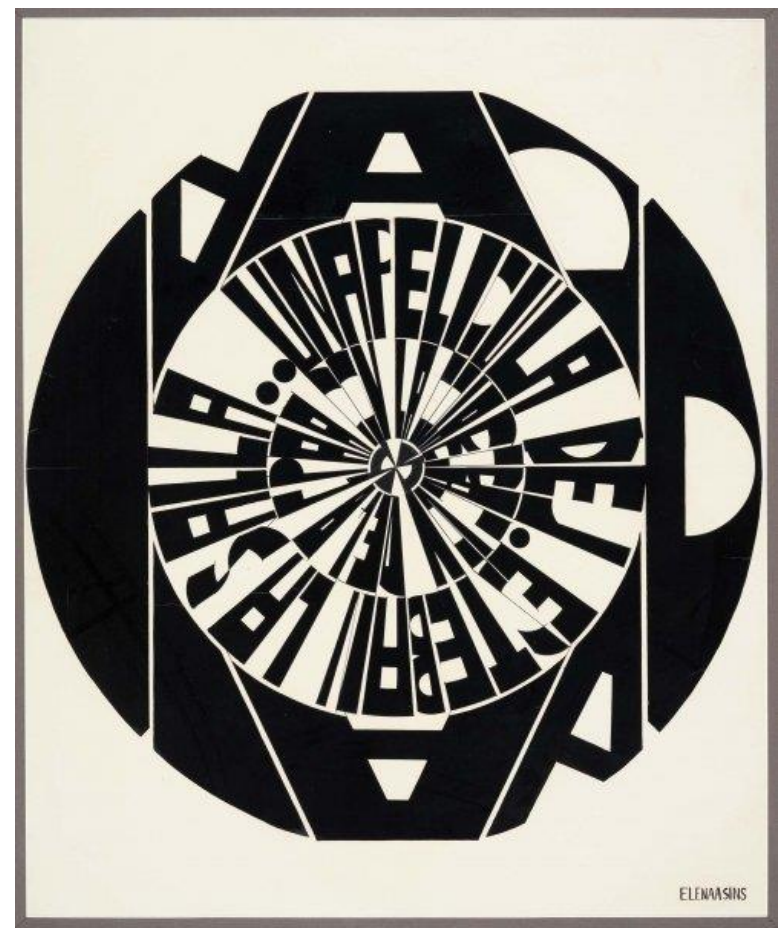

Ese es el Poema circular (una película...), compuesto por Elena Asins en 1968. Podemos observar aquí algunos patrones que se repiten en la poesía de vanguardia que venimos analizando, como la retención del lector dentro del poema y la primacía del acto reflexivo antes del representativo por parte del receptor. De la misma forma que en vai e vem, y en menor medida en gadji beri bimba, el Poema circular de Asins no lanza al lector inmediatamente a la busca de imágenes externas al texto, sino que lo atrapa dentro de un enigma restringido inicialmente al interior del círculo que configura esa pieza poética. Todo esto ya nos parece claro y suficientemente comentado. Ahora queremos aprovechar, con este último ejemplo, para abordar algunos aspectos diferentes a los mencionados anteriormente.

Todo texto literario, además de estar compuesto por signos, puede también ser considerado, en su integridad, como un gran signo, un signo general, con significante y significado. «A ese significado se le pueden atribuir dos modos de significación: o bien se le pretende aparente (...) o bien se le considera secreto» (Barthes, 2009: 88). El poema de Asins es un caso claro de la segunda opción. Guarda secretos. El modo de lectura tradicional no bastará para que se llegue a su significación. El modo de lectura tradicional, por cierto, está

${ }^{5}$ Extraído de https://www.museoreinasofia.es/coleccion/obra/poema-circular-pelicula el 23/06/2020. 
vedado al lector. Primero, porque él, ya de entrada, no va a lograr hacer una lectura lineal, de izquierda a derecha, de arriba abajo. El poema es circular. Segundo, porque, una vez aceptada la lectura circular, el lector tendrá serias dificultades para reconocer los significantes. La recepción, en este punto, podría parecer fallida. Pero, a los lectores de buena voluntad, creemos que les puede ejercer atracción precisamente el aspecto de secreto del texto, su forma enigmática: un círculo perfecto, un curioso juego de contrastes entre blanco y negro, con significantes que parecen ora revelarse, ora esconderse y con letras que van disminuyendo de tamaño hacia el centro, empujando el lector al interior del poema. En este punto, el receptor tendrá plena conciencia de que lo que tiene delante no se puede leer como se leería una novela o un poema no vanguardista. Más que leerlo, el Poema circular hay que verlo; hay que contemplarlo.

Seguimos un poco más con Roland Barthes (2009: 115-119). Nos interesa la originalidad de su análisis sobre «el susurro de la lengua». El pensador francés compara al emisor (ya sea hablando o escribiendo) con un motor mecánico. Cuando el emisor se equivoca, tiene que añadir más texto a su emisión para intentar corregir el error. Dirá, por ejemplo, «no, no es eso», «ahora te lo digo mejor» o algo así. En un mensaje escrito en el que no sea posible el acto de borrar lo ya plasmado en el papel, el redactor tendrá que apañarse para solucionar el equívoco añadiendo más términos al texto, redireccionando y corrigiendo el mensaje fallido. Barthes «llamaría farfullar a esa singularísima anulación por adición», «un ruido de lenguaje comparable a la serie de sacudidas con las que un motor nos hace entender que no está en condiciones», «signo sonoro de un fracaso que se perfila en el funcionamiento del objeto» (2009:115).

Pues bien. En oposición al farfullo estaría el susurro. El motor que no funciona bien farfulla; el motor en perfectas condiciones también emite un sonido, pero un sonido constante, sin sobresaltos, un susurrar. En el susurro del lenguaje, no se distinguen bien los signos lingüísticos. El susurro no llega a ser un mensaje descifrable. Es una ligera masa sonora que existe por su constancia. Es el lenguaje separado del fardo comunicativo, alejado de la obligación de significar. Usamos un ejemplo del propio Barthes: una tarde, viendo el documental de Antonioni sobre China (muy probablemente Chung Kuo), él se fija en una escena en que unos niños chinos están leyendo en voz alta, todos juntos y cada uno para sí mismo, un libro diferente («susurraban como es debido, como una máquina que funciona bien»). Barthes no sabe chino y, aunque lo supiera, le sería complicado identificar los sentidos de tantas lecturas simultáneas. Y concluye: «pero yo oía, en una especie de percepción 
alucinada (...), yo oía la música, el aliento, la tensión, la aplicación, en suma, algo así como una finalidad» (2009: 118) Para el autor, el susurro de la lengua sería:

Un inmenso tejido sonoro en cuyo seno el aparato semántico se encontraría irrealizado; el significante fónico, métrico, vocal, se desplegaría en toda su suntuosidad, sin que jamás se desgajara de él un solo signo (naturalizando esa capa de goce puro), pero también - y ahí está lo difícil- sin que el sentido se eliminara brutalmente, se excluyera dogmáticamente, se castrara, en definitiva. La lengua susurrante confiada al significante en un inaudito movimiento, desconocido por nuestros discursos racionales, no por ello abandonaría un horizonte de sentido: el sentido, indiviso, impenetrable, innominable, estaría, sin embargo, colocado a lo lejos, como un espejismo (...) (Barthes, 2009: 117).

El sentido «colocado a lo lejos, como un espejismo». Es eso lo que venimos hablando diversas veces en este artículo. Gadji beri bimba, vai e vem y, ahora, Poema circular tienen, sí, sentido. Pero, a diferencia de un poema no vanguardista, en nuestros ejemplos el sentido se logra por un camino que quizás podamos llamar indirecto, distinto del sentido inmediato que se alcanza a través del signo lingüístico tradicional y también distinto a los sentidos a los que se llega, a partir de los signos, a través de las concreciones realizadas directamente con el uso de referentes externos a la pieza poética. La formación de sentido en la vanguardia se da a partir de un acto reflexivo sobre el propio lenguaje, lo que por sí solo ya sería una prueba de que el sentido semántico no aparece de inmediato al lector. Antes, está el shock, el impacto y, luego, la reflexión, que, después, podrá venir a originar algún tipo de concreción que dé sentido al poema.

El Poema circular no está compuesto por signos lingüísticos (aunque sea posible encontrar algunos en su interior); él mismo, entero, es un signo. Él no habla; susurra. Hay en él más de una voz, y esas voces se superponen hasta el punto de que no se puede comprender bien lo que quieren decir. Se las puede distinguir, eso sí, porque tienen timbres diferentes, es decir, se puede notar que ocupan diferentes capas emisoras, unas situadas en el perímetro exterior del círculo, escritas con fuentes muy grandes y gruesas, otras más interiores, en fuentes pequeñas y cada vez más finas. De todos modos, como en el caso de los niños chinos leyendo todos a la vez, ninguna de las capas, ni juntas ni por separado, emite mensajes semánticamente inteligibles. Pero la maquinaria funciona a la perfección, y el significante puede desplegarse, retomando las palabras de Barthes, «en toda su suntuosidad». En el Poema circular se pueden ver muchas cosas (nosotros ahora mismo lo estamos mirando y viendo cosas que no habíamos visto antes; incluso una máquina mecánica con sus engranajes girando lentamente en sentidos opuestos; lo podemos ver en tres dimensiones, o al menos esa es la 
sensación que tenemos). En fin, el poder de atracción del Poema circular es algo difícil de negar. Sin embargo, las lecturas caben a los receptores, y no pretendemos ser subjetivos describiendo aquí aspectos de nuestra recepción individual. Volvamos entonces a conceptos más generales.

\section{NUEVOS CAMINOS DE LA VANGUARDIA}

En los principales textos teóricos formadores de la Teoría de la Recepción de la Literatura y también de la Teoría del Efecto Estético, son muy escasos los comentarios, ejemplos y análisis hechos a partir de objetos de estudio oriundos de la literatura vanguardista. Lo que hemos estado haciendo hasta el momento, en este artículo, es transferir conceptos de estas escuelas teóricas al ambiente vanguardista. Uno de ellos, que no hemos tocado todavía y que es una de las ideas centrales abordadas por la Teoría de la Recepción, es la del horizonte de expectativas (Jauss, 1986). No profundizaremos en ella -incluso porque no nos resta espacio para hacer el levantamiento documental que nos llevaría a un análisis más preciso de dicho horizonte-, pero la utilizaremos como vestíbulo para introducir aquí algunas observaciones acerca de la ciberliteratura que, pensamos, pueden ser provechosos para que ya nos vayamos encaminando hacia la conclusión de este estudio.

Seguiremos hablando tomando como base el Poema circular de Asins. Nos parece importante que, antes de nada, hagamos una distinción de público. Los consumidores de literatura en España en la década de 1960 tenían, a grosso modo, dos vertientes principales de oferta literaria: una con carácter oficialista, alabando el territorio español, sus gentes y sus tradiciones, y otra de carácter, podríamos decir, más combativo, políticamente cuestionador e incluso panfletario. En pocas palabras, una acorde con el régimen y otra en desacuerdo. Ambas corrientes adoptaban el corte neo realista, con poca o ninguna atención a las cuestiones estéticas. Sin embargo, ya se vivían en el país ciertos aires de apertura cultural. A finales de los años 1950 y principios de los 60 surgen editoriales como Seix-Barral, Ariel y Taurus, que publican, además de a escritores españoles, algunas traducciones fundamentales para nuevos planteamientos estéticos. En el año 1962, asume el cargo de ministro de información Manuel Fraga Iribarne, personalidad de tintes más liberales si lo comparamos con sus predecesores. En 1966, se aprueba la nueva Ley de Prensa e Imprenta, que atenúa el control de gobierno sobre la cultura. Una de las consecuencias de esa parcial libertad es el 
crecimiento del número de libros y revistas en circulación en España, lo que hace que el mercado cultural experimente cierto desarrollo. Así, al lado de las literaturas en pro y en contra del régimen, empieza a ganar alguna visibilidad la literatura experimental hecha en España -y hagamos aquí justicia: ese tipo de literatura nunca dejó de ser practicada en los ambientes artísticos subterráneos durante la dictadura; basta con recordar el postismo de los años 40, el Dau al Set de los 40 y 50 y el grupo Problemática 63, solo por citar algunos entre tantos posibles ejemplos de resistencia-. Pero, como decíamos, hay que reconocer dos públicos distintos: el primero, numéricamente mayor, consumía las literaturas de corte neo realista, ya fuera de uno u otro bando, y esperaba por más producciones del mismo carácter, que vendrían a reafirmar su posición social y política a través de la literatura. El segundo, mucho más reducido, estaría formado por quien se interesaba por el arte más allá de la política y buscaba piezas artísticas que le conectasen con los nuevos planteamientos estéticos que se estaban llevando a cabo en muchas otras partes del mundo. Del primer grupo, es muy probable que muy pocos hayan tenido acceso, en su época, a obras como el Poema circular. Los que por casualidad lo hayan visto, imaginamos que su recepción derivase a sentimientos de desprecio y rechazo. Entre el segundo grupo, en cambio, su expectativa era precisamente poder ver, por fin, a autores españoles que estuviesen practicando nuevas formas poéticas aliñadas con el desarrollo que se venía practicando internacionalmente. Queremos, aquí, quedarnos con ese corte de público, correspondiente al segundo grupo mencionado.

El horizonte de expectativas que tenían esas pocas personas, posiblemente reunidas en ambientes universitarios de los centros urbanos españoles, era presenciar la entrada del experimentalismo poético dentro del entonces tradicional canon literario de España. El caso de Elena Asins es particularmente interesante, porque, además de producir obras de poesía visual y concreta, lo hacía -a partir de determinado punto de su carrera artística, que podemos fechar en 1967- utilizando un nuevo aparato tecnológico: el ordenador. Asins fue pionera en España de la llamada poesía digital, usando la máquina como herramienta de creación artística, valiéndose del cálculo, de los algoritmos y del lenguaje matemático. Hay que recordar que, obviamente, en aquella época, no se contaba con los programas informáticos de hoy, lo que hizo que Elena Asins tuviese que volcarse en el aprendizaje de la programación -pero siempre con el objetivo de producir arte-, algo novedoso no solamente en España, sino ya también a nivel mundial. De ahí creemos sea posible deducir que un poema como el Poema circular, más que cumplir con la expectativa de ese pequeño grupo de lectores abiertos al experimentalismo, excedía sus expectativas. Eso significa que obras como el Poema circular 
instauran en el panorama literario una nueva forma de percibir la literatura, obligando incluso a receptores preparados para la vanguardia a replantear su modo de recepción. Ya no se trata solamente de la diferencia entre lenguaje cotidiano y lenguaje poético (como nos demostraron los formalistas rusos), ni siquiera entre lo poético no vanguardista y lo poético vanguardista, sino entre lo «vanguardista tradicional» (así lo podemos llamar, conscientes de la gran contradicción que guarda el término) y lo «vanguardista cibernético». Aclaremos, en este momento, que la poesía cibernética no es simplemente la poesía hecha con el ordenador, sino específicamente la poesía que usa los recursos informáticos como rasgo distintivo de su resultado, como pueden ser el color y la tipografía, y también el sonido y el movimiento, estos últimos exclusivos de la construcción poética informática.

Cuando Elena Asins empezó, en España, a hacer uso de la herramienta informática para composición de piezas artísticas, estaba rompiendo moldes en cuanto al manejo de un nuevo aparato -el ordenador- capaz de aportar novedades productivas. Pero, a la vez, daba un paso más en la línea evolutiva de la poesía experimental empezada casi un siglo antes por Stéphane Mallarmé, continuada por las vanguardias históricas de principios del siglo xx y, después, por las vanguardias de la postguerra en los años 1950 y 60. Nos parece un ejercicio placentero imaginar, por ejemplo, como habrían disfrutado Tristan Tzara, Marinetti o el propio Mallarmé con un aparato informático en las manos. Si no lo usaron -creemos firmemente- es porque no existía. La curiosidad, el afán por lo moderno y el deslumbramiento por la maquinaria tecnológica de sus épocas eran características personales de esos y de muchos otros vanguardistas, y nos pueden llevar a creer en tal hipótesis. Más allá de esos ejercicios de imaginación, sabemos que la poesía cibernética es hoy en día una realidad, no exenta de críticas, desconfianzas y detracciones, pero una indudable realidad. Pese a su relativa juventud, la e-poesía, como también la podemos llamar, ya es un hecho integrado en el panorama literario mundial, merecedora de la atención no solamente de poetas sino también del universo teórico académico. Su concepto es amplio y abarca diferentes modalidades de manejo de la máquina para la producción de poemas, lo que puede originar distintos caminos receptivos al lector y también, obviamente, provoca cambios muy importantes en la circulación y difusión de la literatura. De los poemas visuales hechos en papel derivan poemas visuales animados. Si muchos de los poemas concretos de antiguamente se acercaban al campo de las artes plásticas, los e-poemas dinámicos de ahora se acercan al cine o incluso al videojuego. La recepción, está claro, también es objeto de grandes cambios. La participación del lector gana aires nunca antes vistos, principalmente si 
pensamos en el uso del hipertexto y en el manejo del ratón para la elección explícita por parte del receptor del camino de lectura que quiere seguir. También, los modos de percepción de un poema en movimiento demandan nuevos estudios de recepción. Si en piezas como vai e vem y Poema circular el carácter dinámico es sugerido al lector por la disposición de los signos en el papel, en los poemas animados ese movimiento de las letras y palabras es real, lo que también puede pasar con los sonidos y la sensación de tridimensionalidad. Lo cierto es que los estudios de recepción de la vanguardia nos empujan ahora, inevitablemente, a bucear en el campo de la cibernética, porque es ahí, en ese nuevo soporte, dónde ella viene desarrollándose con más visibilidad y potencia. En este artículo hemos apuntado diversos hechos relacionados con la lectura de poemas vanguardistas del siglo pasado. Sin quitarle importancia a nuestros propios análisis, reconocemos que pueden saber a poco, porque la vanguardia sigue y siempre seguirá, no es estática y no se ha quedado anclada en siglos pasados. A quienes tengan interés en estudiar la recepción de la vanguardia, les tocaría ahora sumergirse en ese nuevo mundo que se nos abre ante los ojos. Como ya hemos comentado antes, un buen camino puede ser comenzar por un análisis que busque encontrar respuestas acerca de los rasgos distintivos entre la vanguardia pre cibernética y la vanguardia cibernética, abordando a partir de ahí las cuestiones de recepción y de efecto estético.

\section{CONCLUSIÓN}

Cuando intitulamos este artículo como «Poemas para no leer», queríamos referirnos a otras formas de lectura que no se restringen a la recepción de los signos lingüísticos tradicionales a través del sistema de representaciones que empieza con el significante y termina obligatoriamente en un significado previamente establecido por el contrato lingüístico firmado entre los hablantes de un idioma. Pensamos que ha quedado bastante claro, a través de las piezas poéticas fonéticas y visuales que hemos utilizado como ejemplo, que existe mucha significación más allá de la semántica. Lo estético también significa. Lo estético no es solamente forma, sino también fondo. El texto poético no se reduce al signo lingüístico tradicional; lo sobrepasa. Eso es así en la poesía no vanguardista y, más acentuadamente, en la vanguardista.

En la introducción, hablábamos de una clasificación textual que tuviera en cuenta el criterio de la intención informativa versus la intención estética. Bajo ese punto de vista, el 
texto de un manual de un horno microondas y el texto de un poema vanguardista tendrían prácticamente como único punto común el hecho de que están formados por letras. Tendrían entre ellos una lejana relación de parentesco, que puede ser captada porque los dos utilizan material lingüístico para comunicarse. Pero la semejanza entre ellos pararía por ahí. Ahora bien, si se trata de tipos de texto tan diferentes, creemos que su recepción también tendría que partir de bases diferentes. Y es ahí que entramos en el punto con el que nos gustaría concluir este artículo: la importancia de la educación formal, de la escuela.

Cuando aprendemos a leer, casi toda nuestra atención -de alumnos y de profesores- está volcada al aspecto semántico del signo lingüístico. Eso es comprensible, ya que la escuela prepara los alumnos para la vida práctica, y en la vida práctica es más importante saber decodificar un manual de microondas que llegar a la fruición estética a través de un poema vanguardista. Incluso cuando se habla de literatura, la primacía suele recaer en el sentido de la «historia» de tal libro o poema; o peor, se intenta en clase sacar su «moraleja». Barthes (2009: 94) nos hace una interesante reflexión en cuanto a eso:

La reducción de la lectura a un consumo es evidentemente responsable del «aburrimiento» que muchos experimentan ante el texto moderno («ilegible»), la película o el cuadro de vanguardia: aburrirse, en este caso, quiere decir que no se es capaz de producir el texto, de ejecutarlo, de deshacerlo, de ponerlo en marcha.

Pensamos que sería posible plantearse, al lado de la enseñanza tradicional de la lectura, un enfoque que priorizase la aprehensión estética de los textos y, a partir de ella, otro camino para la formación de sentido. Claro está que, en ese campo, tendríamos que trabajar hermanados con pedagogos. Creemos que, desde edades tempranas, los receptores tendrían que recibir ese otro tipo de formación lectora, y que se acostumbrasen a ver en el material lingüístico más que una fuente de significados semánticos, sino también una poderosa herramienta transmisora de aspectos estéticos, sonoros y visuales. Esa visión serviría para dotar a las nuevas generaciones de un potencial de recepción mucho más amplio que el que tenemos ahora, contribuyendo al desarrollo de nuevas experimentaciones poéticas a lo mejor ni siquiera imaginadas por nosotros hoy en día. Es posible, incluso, que las niñas y niños tengan ese potencial mucho más desarrollado que los adultos, y lo que hace la escuela es lijar esa posible tendencia infantil de lectura estética de los signos lingüísticos.

Desde Mallarmé hasta la actual e-poesía, un buen camino ya ha sido recorrido. Pero hace falta más. El aprendizaje del modo de aprehensión estética de los textos no se puede restringir a los círculos lectores de obras vanguardistas. Para que la poesía en general, y la 
poesía vanguardista en particular, deje de ser lectura para pocos y amplíe su ámbito, es necesario, antes, la formación de contingentes de receptores preparados no solamente para leer los poemas, sino para aprehenderlos como la unidad estética que son. 


\section{BIBLIOGRAFÍA}

Adorno, Theodor (2004): Teoría Estética, traducción al español de Jorge Navarro Pérez, Madrid, Akal.

Barthes, Roland $\left(2012^{19}\right)$ : Elementos de semiologia, traducción al portugués de Izidoro Blikstein, São Paulo, Cultrix.

Barthes, Roland (2009): El susurro del lenguaje - más allá de la palabra y la escritura, traducción de C. Fernández Medroño, Barcelona, Paidós.

Benjamin, Walter (2003): La obra de arte en la época de su reproductibilidad técnica, traducción al español de Andrés Weikert, México D. F., Ítaca.

Bürger, Peter (2010): Teoría de la vanguardia, traducción al español de Tomás Bartoletti, Buenos Aires, Las Cuarenta.

Campos, Augusto de; Décio Pignatari, Haroldo de Campos (2006): Teoria da poesia concreta textos críticos e manifestos 1950-1960. São Paulo, Ateliê Editorial, $4^{a}$ ed.

Iser, Wolfgang (1996): O ato da leitura - uma teoria do efeito estético, traducción al portugués de Johannes Kretschmer, São Paulo, Editora 34.

Jauss, Hans Robert (1986): Experiencia estética y hermenéutica literaria, traducción al español de Jaime Siles y Ela Fernández-Palacios, Madrid, Taurus.

Mayoral, José Antonio (coord.) (1987): Estética de la recepción. Madrid, Arco Libros.

Mukarovsky, Jan (1971): Arte y semiología, traducción al español de Simón Marchán Fiz, Madrid, Alberto Corazón Editor.

Ortega y Gasset, José (2016): La deshumanización del arte y otros ensayos de estética. Barcelona, Espasa.

Saussure, Ferdinand de (2012): Curso de linguística geral, traducción al portugués de Antônio Chelini, José Paulo Paes y Izidoro Blikstein, São Paulo, Cultrix, $28^{a}$ ed.

Sánchez-Mesa, Domingo (org.) (2004): Literatura y Cibercultura. Madrid, Arco Libros.

Torre, Guillermo de (1965): Historia de las literaturas de vanguardia. Madri: Visor Libros.

Warning, Rainer (ed.) (1989): Estética de la recepción, traducción al español de Ricardo Sánchez Ortiz de Urbina, Madrid, Visor Libros. 
SOBRE EL AUTOR

\section{Sérgio Massucci Calderaro}

Licenciado por la Escola Superior de Propaganda e Marketing (São Paulo, Brasil), Doctor en CC. de la Información por la Universidad Complutense de Madrid y Doctor en Teoría Literaria y Literatura Comparada por la Universidad de São Paulo. En Brasil, fue profesor de la Universidad Estácio de Sá y, en España, profesor interino del área de portugués de la Facultad de Filología de la Universidad Complutense de Madrid. Ha sido asesor de Prensa y Divulgación de la Embajada de Brasil en España. Forma parte del grupo de investigación NELOOL (Núcleo de Estudios Literarios, de Oralidad y Otros Lenguajes), de la Universidad Federal de Santa Catarina (Brasil). Es autor de la novela A Ilba Urbana y del libro didáctico Manual do Futuro Redator. Desde 1990 trabaja como redactor y corrector de textos para empresas de comunicación.

\section{Contact information:}

Correo electrónico: sergimas@ucm.es / massucci.calderaro@gmail.com 